\title{
Small quantities of respiratory syncytial virus RNA only in large droplets around infants hospitalized with acute respiratory infections
}

Jasmin S. Kutter ${ }^{1}$, Dennis de Meulder ${ }^{1}$, Theo M. Bestebroer ${ }^{1}$, Jeroen J. A. van Kampen ${ }^{1}$, Richard Molenkamp', Ron A. M. Fouchier ${ }^{1}$, Jérôme O. Wishaupt ${ }^{2}$, Pieter L. A. Fraaij, ${ }^{1,3}$ and Sander Herfst ${ }^{*}$ (D)

\begin{abstract}
Background: Respiratory syncytial virus (RSV) is a major cause of respiratory tract infections in young children. The predominant transmission routes for RSV are still a matter of debate. Specifically, it remains unclear if RSV can be transmitted through the air and what the correlation is between the amount of RSV in nasopharynx samples and in the air.

Methods: The amount of RSV in the air around hospitalized RSV infected infants in single-patient rooms was quantified using a six-stage Andersen cascade impactor that collects and fractionates aerosols and droplets according to size. RSV shedding in the nasopharynx of patients was followed longitudinally by quantifying RSV RNA levels and infectious virus in nasopharyngeal aspirates. Nose and throat swabs of parents and swabs of the patient's bedrail and a datalogger were also collected.

Results: Patients remained RSV positive during the air sampling period and infectious virus was isolated up to 9 days post onset of symptoms. In three out of six patients, low levels of RSV RNA, but no infectious virus, were recovered from impactor collection plates that capture large droplets $>7 \mu \mathrm{m}$. For four of these patients, one or both parents were also positive for RSV. All surface swabs were RSV-negative.

Conclusions: Despite the prolonged detection of infectious RSV in the nasopharynx of patients, only small amounts of RSV RNA were collected from the air around three out of six patients, which were primarily contained in large droplets which do not remain suspended in the air for long periods of time.
\end{abstract}

Keywords: Air sampling, Viable six-stage Andersen cascade impactor, Respiratory syncytial virus, Transmission routes, Droplet transmission

\section{Background}

Respiratory syncytial virus (RSV) is a major cause of lower respiratory tract infections (LRTIs) in young children, that may be severe $[1,2]$. Two antigenically different subtypes of RSV, A and B, often co-circulate, but usually one subtype predominates [3-7]. By the age of two, nearly all children have been infected with RSV at least

\footnotetext{
*Correspondence: s.herfst@erasmusmc.nl

1 Department of Viroscience, Erasmus University Medical Center, Dr. Molewaterplein 50, 3015 GE Rotterdam, The Netherlands

Full list of author information is available at the end of the article
}

once $[8,9]$. For 2015 it was estimated that approximately 33 million children under the age of 5 suffered from an LRTI caused by RSV worldwide, of which 3.2 million required hospitalization, resulting in almost 30.000 inhospital deaths [2].

Respiratory viruses can be transmitted via different transmission routes: via direct contact, e.g. through handshaking with an infected person, via indirect contact by touching contaminated surfaces, or via the air through droplets and/or aerosols that are expelled by an infected person [10]. Droplets quickly settle on the original author(s) and the source, provide a link to the Creative Commons licence, and indicate if changes were made. The images or other third party material in this article are included in the article's Creative Commons licence, unless indicated otherwise in a credit line to the material. If material is not included in the article's Creative Commons licence and your intended use is not permitted by statutory regulation or exceeds the permitted use, you will need to obtain permission directly from the copyright holder. To view a copy of this licence, visit http://creativecommons.org/licenses/by/4.0/. The Creative Commons Public Domain Dedication waiver (http://creativeco mmons.org/publicdomain/zero/1.0/) applies to the data made available in this article, unless otherwise stated in a credit line to the data. 
ground or objects in near vicinity of the source, while aerosols are small enough to remain suspended in the air for prolonged periods of time and can infect susceptible individuals further away from the source. For this reason, depending on the transmission properties of the pathogen, droplet or aerosol precautions are implemented [10].

To date, it has been widely accepted that short distances or close contact between individuals are needed for efficient RSV transmission, and as a result, contact and droplet precautions are implemented in infection prevention guidelines globally [10]. However, the scientific data to support these guidelines is scarce, and often contrasting [10]. In the 1980s it was demonstrated that healthy individuals only became infected upon self-inoculation after touching contaminated surfaces, or through close contact with infected infants, but not by solely sitting in the same room at a distance of $>1.8 \mathrm{~m}$ away from the patient's bed [11]. These observations were later supported by several air sampling studies, in which RSV was detected infrequently, or not at all, in the air around infected patients [12-15]. In contrast to these studies, Aintablian and colleagues were able to collect RSV RNA from the air around RSV infected patients between 0.3 and $7 \mathrm{~m}$ away from the patient's head, with a higher likelihood of RSV detection close to the patient [16]. Other researchers recently collected large quantities of infectious RSV in the air around RSV-infected children in a pediatric ward, up to $5 \mathrm{~m}$ from the head of an index case [17].

Because of these conflicting experimental data, the likelihood of RSV being transmitted through the air is still unknown. Here, the amount of RSV in the air around infants ( $<2$ years) hospitalized with RSV infections was quantified longitudinally and correlated to the RSV load in upper respiratory tract samples of these patients. With a six-stage Andersen cascade impactor that collects droplets and aerosols according to size, RSV RNA was collected from the air around three out of six infants and was found to be predominantly present in droplets $>7 \mu \mathrm{m}$. We did not detect infectious virus in any air fractions and did not detect RSV RNA in finer aerosols, whereas such finer aerosol fractions did contain rhinovirus RNA.

\section{Materials and methods \\ Patients}

The study was conducted during three consecutive winter seasons (November 2017-April 2020) at the department of pediatrics at the Reinier de Graaf Hospital, Delft, The Netherlands. Hospitalized children aged between 0 and 2 years with laboratory-confirmed RSV-A or RSV-B infections were both eligible. However, during these three seasons, only RSV-B positive patients were detected in the study. Patients were excluded if they were older than 2 years, or if signed informed consent was not obtained. For practical reasons, immunocompromised patients and patients that were experiencing symptoms for more than a week prior to hospitalization were not included. Patients with other co-morbidities, with viral co-infections, or use of medication, including antivirals, were not excluded, but this information was documented together with other clinical data obtained from the patient's medical record using a standardized case record form, specifically developed for this study. Patients were hospitalized in single-patient rooms with an additional bed for parents. All patient rooms had a ventilation rate of 2 air changes per hour $(\mathrm{ACH})$ with a fresh air transportation rate of $100 \mathrm{~m}^{3} / \mathrm{h}$. Temperature and relative humidity were recorded every five minutes during the whole air sampling period using EL-GFX-2 dataloggers (Lascar Electronics Inc.).

\section{Sample collection}

For the collection of RSV from the air, the six-stage Andersen cascade impactor (Thermo Scientific ${ }^{\mathrm{TM}}$ ) was used [18]. The cascade impactor operates at a flow rate of $28.3 \mathrm{~L}$ per minute (LPM) and collects droplets and aerosols according to size in six different stages: Stage $1(>7.0 \mu \mathrm{m})$, stage $2(7.0-4.7 \mu \mathrm{m})$, stage $3(4.7-3.3 \mu \mathrm{m})$, stage $4(3.3-2.1 \mu \mathrm{m})$, stage $5(2.1-1.1 \mu \mathrm{m})$ and stage 6 $(1.1-0.65 \mu \mathrm{m})$. The air inlet of the cascade impactor was positioned approximately $1 \mathrm{~m}$ away from the patient's head at a height of $109 \mathrm{~cm}$. Air was sampled daily for $30 \mathrm{~min}$, starting the day after the informed consent was obtained, until discharge or a maximum of five days. To prevent contamination of samples, air sampling was performed in the morning, prior to routine care that may involve aerosol generating procedures like nasopharyngeal aspiration. Droplets and aerosols were impacted onto collection plates filled with an in-house developed semi-solid gelatin layer, as previously described [19]. The gelatin layer was prepared from commercial gelatin sheets $(10 \mathrm{mg} / \mathrm{ml}$; Dr. Oetker) dissolved in virus transport medium (VTM). VTM consisted of Minimum Essential Medium (MEM) - Eagle with Hank's BSS and $25 \mathrm{mM}$ Hepes (Lonza), glycerol 99\% (Sigma Aldrich), lactalbumin hydrolysate (Sigma Aldrich), $10 \mathrm{MU}$ polymyxin B sulphate (Sigma Aldrich), $5 \mathrm{MU}$ nystatin (Sigma Aldrich), $50 \mathrm{mg} / \mathrm{ml}$ gentamicin (Gibco) and $100 \mathrm{IU} / \mathrm{ml}$ penicillin $100 \mu \mathrm{g} / \mathrm{ml}$ streptomycin mixture (Lonza). To avoid high dilution factors, each collection plate was first filled with $32 \mathrm{ml}$ of $2 \%$ agarose (Roche) as a bottom layer on which $9 \mathrm{ml}$ of the semi-solid gelatin was pipetted. Subsequently, plates were stored at $+4{ }^{\circ} \mathrm{C}$ for a maximum of 4 days.

On the last day of air sampling, surface swabs were taken using Copan flocked swabs (Copan Diagnostics 
Inc.) from the datalogger and the bed rail on the side where the cascade impactor was located. From the first day of air sampling onwards, nasopharyngeal aspirates (for decongestion) were obtained from patients during routine clinical care if available, and otherwise aspirates or nose swabs were taken specifically for this study if consent was given by the parents. From each parent, nose or throat swabs (either Copan $\mathrm{eSwab}^{\circledR}$ or Copan flocked swabs (Copan Diagnostics Inc.)) were taken on the first and last day of air sampling, when possible, to estimate their contribution to viral shedding in the air.

\section{Sample processing}

The collection plates with gelatin from the cascade impactor were processed after sampling by adding $6 \mathrm{ml}$ of prewarmed VTM, followed by a 30 min incubation at $37{ }^{\circ} \mathrm{C}$ to dissolve the gelatin layer and harvesting of the samples [19]. Nose and throat swabs of parents were collected in Amies (eSwab ${ }^{\circledR}$; Copan Diagnostics Inc.) or universal transport medium (UTM; flocked swabs; Copan Diagnostics Inc.). VTM was added to the nasopharyngeal aspirates of patients and nose and throat samples of parents to reach a total volume of $6 \mathrm{ml}$, after which nasopharyngeal aspirates were centrifuged at $500 \mathrm{G}$ for $5 \mathrm{~min}$ to remove cell debris. All samples were subsequently aliquoted and stored at $+4{ }^{\circ} \mathrm{C}$ for a maximum of 4 days until further analysis. An additional vial of each sample was stored at $-80{ }^{\circ} \mathrm{C}$. The surface swabs were collected in UTM (flocked swabs; Copan Diagnostics Inc.), and stored in $25 \%$ sucrose at $-80{ }^{\circ} \mathrm{C}$. At the end of the study, the samples were thawed and RNA was extracted followed by qRT-PCR analysis.

\section{Cells}

Hep-2 cells were cultured in Dulbecco's Modified Eagle Medium (DMEM, Lonza or Gibco) supplemented with $10 \%$ fetal bovine serum (FBS) (Greiner or Atlanta Biologicals), $100 \mathrm{IU} / \mathrm{ml}$ penicillin $100 \mu \mathrm{g} / \mathrm{ml}$ streptomycin mixture (Lonza), $200 \mathrm{mM}$ L-glutamine (Lonza), $1.5 \mathrm{mg} /$ $\mathrm{ml}$ sodium bicarbonate (Lonza), $10 \mathrm{mM}$ HEPES (Lonza) and $0.25 \mathrm{mg} / \mathrm{ml}$ fungizone (Invitrogen). The cells were maintained at $37^{\circ} \mathrm{C}$ and $5 \% \mathrm{CO}_{2}$.

\section{RNA extraction and qRT-PCR}

RNA was extracted from the samples using the MagNA Pure LC Total Nucleic Acid Isolation Kit (Roche) and subjected to qRT-PCR analysis for the detection of RSV-B RNA, and in case of the rhinovirus (RV) co-infected patients also for RV RNA [20]. For this purpose, $20 \mu \mathrm{l}$ of extracted virus RNA was amplified in a final volume of $30 \mu \mathrm{l}$, containing 7,5 $\mu \mathrm{l}$ 4xTaqMan Fast Virus 1-Step Master Mix (Life Technologies) and $1 \mu$ l Primer/Probe mixture [20]. Amplification was performed using the following protocol: 5 min $50{ }^{\circ} \mathrm{C}, 20 \mathrm{~s} .95^{\circ} \mathrm{C}, 45$ cycles of 3 s. $95^{\circ} \mathrm{C}$ and 31 s. $60{ }^{\circ} \mathrm{C}$. For all samples, a cycle threshold $(\mathrm{Ct})$ value of $>40$ was considered negative.

\section{Virus titration}

RSV-B-positive samples were titrated on Hep-2 cells for the quantification of infectious virus, as defined by the culturability of RSV. Briefly, Hep- 2 cells were grown to confluency in 96 well plates overnight. Subsequently, cells were spin-inoculated (15 min, $2000 \mathrm{rpm}$ ) with $100 \mu \mathrm{l}$ of 10 -fold serial dilutions of RSV-B positive samples and incubated at $37{ }^{\circ} \mathrm{C}, 5 \% \mathrm{CO}_{2}$. One hour after inoculation, cells were washed once and cultured in serum-reduced (2\%) Dulbecco's Modified Eagle Medium (DMEM, Lonza) supplemented with $100 \mathrm{IU} / \mathrm{ml}$ penicillin $100 \mu \mathrm{g} /$ $\mathrm{ml}$ streptomycin mixture (Lonza), $200 \mathrm{mM} \mathrm{L}$-glutamine (Lonza), $1.5 \mathrm{mg} / \mathrm{ml}$ sodium bicarbonate (Lonza), $10 \mathrm{mM}$ HEPES (Lonza) and $0.25 \mathrm{mg} / \mathrm{ml}$ fungizone (Invitrogen). After 7 days of incubation, positive samples were identified by immunofluorescence assays using a FITC labelled polyclonal antibody directed against RSV (Fisher Scientific). Infectious virus titers were calculated from four replicates as tissue culture infective dose $\left(\mathrm{TCID}_{50}\right)$ by the Spearman-Karber method.

\section{Results}

\section{Clinical setting and patient demographics}

Six infants with ages ranging from 10 days to 7 months (median age 2 months) were included over the course of three consecutive winter seasons (Nov 2017-Mar 2020), of whom two were female and four were male (Table 1). No comorbidities were reported, however, patient 1 was born at a gestational age of 36 weeks. All patients had RSV-B confirmed infections with the majority of infections manifesting as bronchiolitis and/or dyspnea. Two patients were diagnosed with a rhinovirus (RV) co-infection at the day of hospital admission. All infants received non-invasive positive airway pressure ventilation with supplemental oxygen. Standard treatment was only supportive aimed at relieving symptoms (Table 1 ). All infants were hospitalized in single-patient rooms together with one in-rooming parent. Ambient room temperature and relative humidity were monitored in each room and were on average $21.7{ }^{\circ} \mathrm{C}$ and $45.5 \%$, respectively (Table 2 ).

\section{RSV load in patients and parents}

To study the virus shedding kinetics in patients, both the RSV RNA levels, as well as the amount of infectious virus, were determined in the nasopharyngeal aspirates that were collected over time. For patient 2, only one nasopharyngeal aspirate was obtained, because the parents did not consent to obtain an aspirate solely for the purpose of this study. For this reason, it is unknown if 


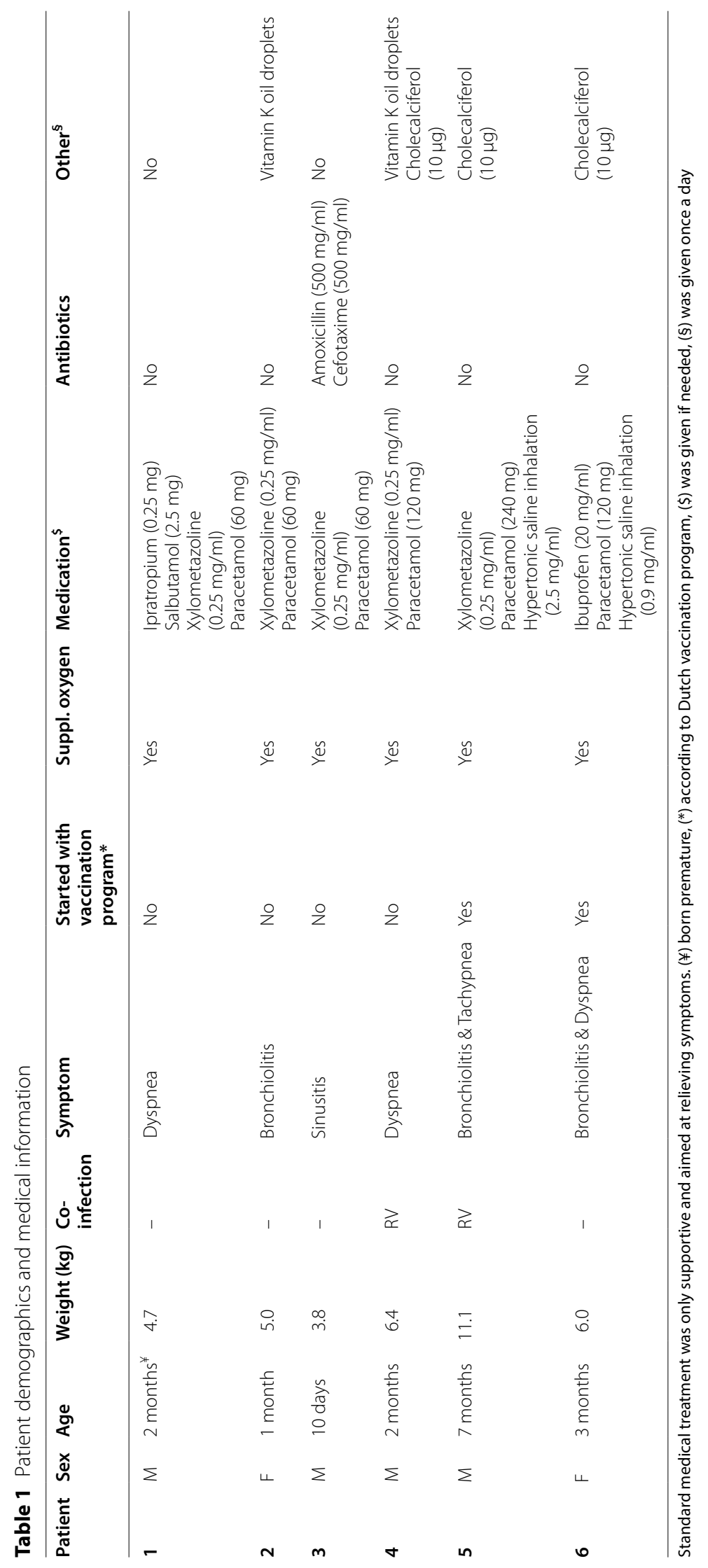


Table 2 Overview of environmental conditions and Ct values in air samples and samples from patients and parents

\begin{tabular}{|c|c|c|c|c|c|c|c|c|c|}
\hline \multirow[t]{2}{*}{ Patient } & \multirow[t]{2}{*}{$\begin{array}{l}\text { Days between symptom } \\
\text { onset and } 1 \text { st day of } \\
\text { sampling }\end{array}$} & \multicolumn{2}{|c|}{$\begin{array}{l}\text { Ambient } \\
\text { room } \\
\text { temperature } \\
\left({ }^{\circ} \mathrm{C}\right) \\
\end{array}$} & \multicolumn{2}{|c|}{$\begin{array}{l}\text { Room relative } \\
\text { humidity (\%) }\end{array}$} & \multirow[t]{2}{*}{$\begin{array}{l}\text { Ct value of RSV } \\
\text { air sample (day) }\end{array}$} & \multirow[t]{2}{*}{$\begin{array}{l}\text { Ct value of } \\
\text { RV air sample } \\
\text { (day) }\end{array}$} & \multirow[t]{2}{*}{$\begin{array}{l}\text { Ct value of } \\
\text { father for RSV } \\
\text { (day) }\end{array}$} & \multirow[t]{2}{*}{$\begin{array}{l}\text { Ct value of } \\
\text { mother for RSV } \\
\text { (day) }\end{array}$} \\
\hline & & Average & SD & Average & SD & & & & \\
\hline 1 & Unknown & 21.8 & 0.1 & 47.9 & 3.9 & $34.9(2)$ & - & $\begin{array}{l}28.2(4) \\
31.4(5)\end{array}$ & $\begin{array}{l}21.4(1) \\
33.6(5)\end{array}$ \\
\hline 2 & 4 & 22.0 & 0.2 & 48.8 & 3.9 & $\begin{array}{l}33.5(2) \\
35.8(5)\end{array}$ & - & $\begin{array}{l}\mathrm{Neg}(1) \\
\mathrm{Neg}(4)\end{array}$ & $\begin{array}{l}\operatorname{Neg}(1) \\
35.5(4)\end{array}$ \\
\hline 3 & 6 & 21.7 & 0.1 & 42.2 & 2.1 & $34.9(2)$ & - & $\operatorname{Neg}(1)$ & $\begin{array}{l}\operatorname{Neg}(1) \\
\operatorname{Neg}(5)\end{array}$ \\
\hline 4 & 6 & 21.8 & 0.4 & 43.5 & 1.9 & Neg & $\begin{array}{l}35.7(2) \\
35.3(2) \\
37.8(4) \\
35.6(5)\end{array}$ & $\begin{array}{l}31.8(1) \\
33.3(5)\end{array}$ & $\begin{array}{l}\operatorname{Neg}(1) \\
\operatorname{Neg}(5)\end{array}$ \\
\hline 5 & 5 & 21.5 & 1.0 & 45.6 & 3.4 & Neg & Neg & $\begin{array}{l}22.4(1) \\
20.4(1)\end{array}$ & $\begin{array}{l}\operatorname{Neg}(1) \\
\operatorname{Neg}(3)\end{array}$ \\
\hline 6 & 7 & 21.7 & 0.1 & 44.6 & 3.9 & Neg & - & Neg (3) & $\operatorname{Neg}(2)$ \\
\hline
\end{tabular}

this patient remained RSV positive during the sampling period. However, the other five patients were qRT-PCR positive during the entire sampling period (Fig. 1). In four patients, infectious RSV was isolated from the nasopharyngeal aspirates on more than one day. For RV coinfected patients, aspirates were RV-positive by qRT-PCR on all days except on day 5 (Patient 4) and day 2 and 3 (Patient 5) after hospital admission (Fig. 1).

Since parents stayed with their children during hospitalization, it was possible that they became infected as well. For this reason, nose or throat swabs were collected from the parents. For four patients, at least one parent tested positive for RSV-B by qRT-PCR (Fig. 1). For patient 1, both parents were found to be RSV-B positive by qRT-PCR. All parents of RV co-infected patients tested negative for RV. High levels of RSV RNA, similar to those in the patients, were detected in swabs collected from the mother of patient 1 and the father of patient 5 , but no infectious virus was detected (Table 2).

\section{RSV in air and on surfaces}

Air sampling in patient rooms was started 4 to 7 days (median 6 days, Table 2) after the onset of symptoms. In three out of six patient rooms, RSV RNA was collected from the air on at least one day (Fig. 1). For patient 1 and 3 , RSV RNA was detected on day 3 and 2 after hospital admission, respectively. In the room of patient 2, RSV RNA was detected in air samples intermittently on days 2 and 5 after admission. All RSV RNA positive air samples originated from stage 1 with the largest droplet particle size $(>7 \mu \mathrm{m})$. The quantities of virus RNA retrieved from the RSV-positive samples were low ( $\mathrm{Ct}$ values ranging between 33.5 and 35.8) and no infectious virus was detected (Table 2).

For one of the two patients co-infected with RV, air samples were positive for RV RNA (patient 4). Stage 1 (particles $>7 \mu \mathrm{m}$ ) was positive for RV RNA on day 2 and stage 3 (particles between 4.1 and $3.3 \mu \mathrm{m}$ ) was positive on days 2,4 , and 5 after admission. RV RNA levels were also low, with $\mathrm{Ct}$ values ranging between 35.3 and 37.8 (Table 2; Fig. 1).

To investigate if RSV and RV were also present on surfaces, the bedrail on the side of the cascade impactor and the datalogger which was placed approximately 1.5-2 $\mathrm{m}$ from the patient's head were swabbed on the day of discharge (Table 3). A bedrail swab of patient 6 is missing because the bedrail had already been disinfected and cleaned before a sample could be obtained. No RSV or RV RNA was detected in any of the surface swabs by qRT-PCR.

\section{Discussion}

Despite the substantial impact of RSV globally, it is still unclear via which routes RSV is primarily transmitted and if and how long infectious virus is shed by infected individuals. Here, we determined the amount of RSV in the air around hospitalized infants, in correlation with the viral load in their upper respiratory tract over time. We demonstrated that despite the presence of infectious RSV in nasopharyngeal samples of infants, only low amounts of RSV RNA, but no infectious virus, were detected in the air around three out of six patients. RSV RNA was only detected in large $(>7 \mu \mathrm{m})$ droplets.

For two of these patients, one or both parents also tested positive for RSV, so they may have contributed to 


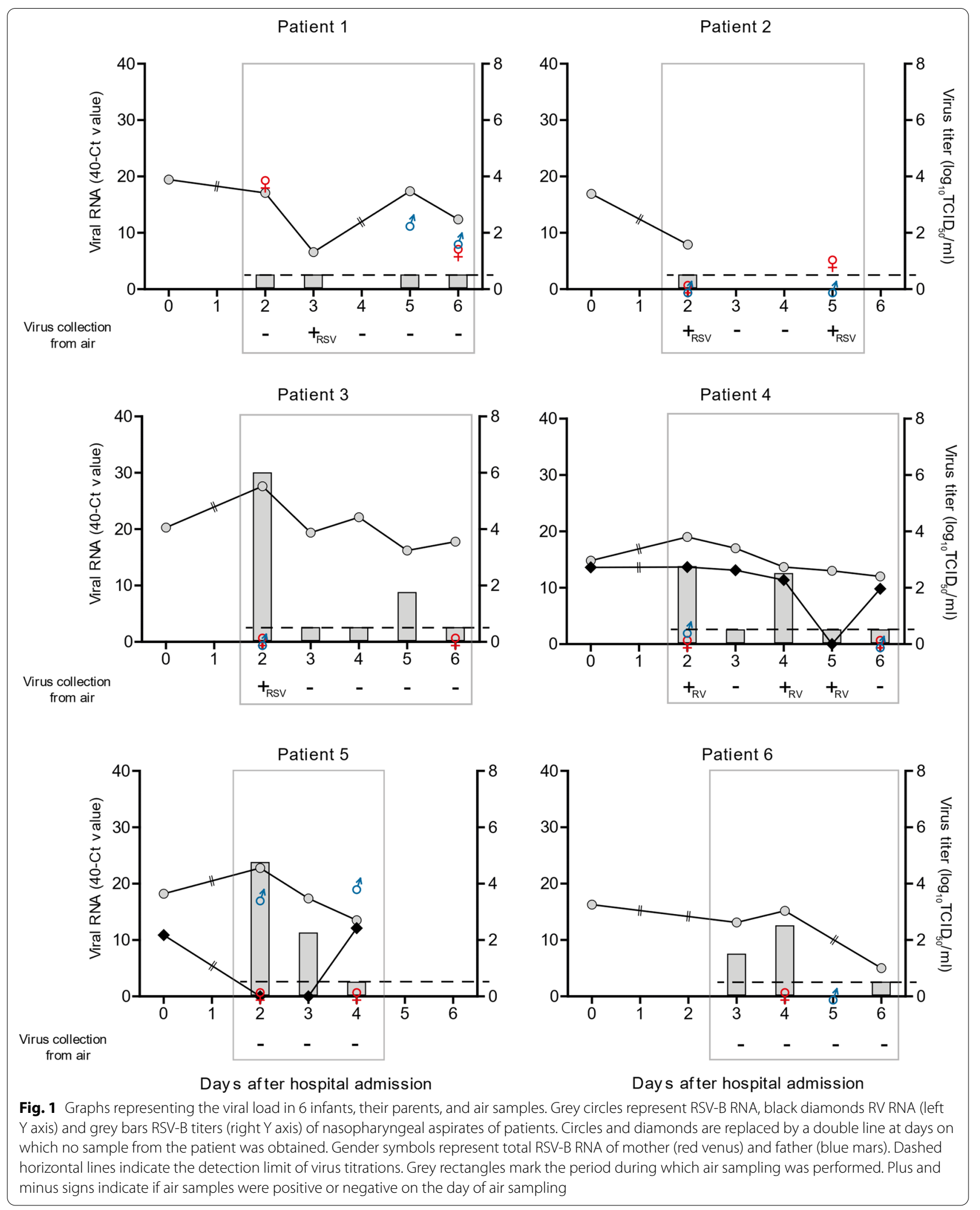


Table 3 Detection rate of RSV and RV in all collected samples

\begin{tabular}{llll}
\hline Sample & $\begin{array}{l}\text { \# of samples } \\
\text { obtained }\end{array}$ & \multicolumn{2}{l}{ \# of samples positive } \\
\cline { 3 - 4 } & & $\begin{array}{l}\text { Total viral } \\
\text { RNA }\end{array}$ & $\begin{array}{l}\text { Infectious } \\
\text { virus }\end{array}$ \\
\hline Nasopharyngeal aspirates & 21 & 21 & 8 \\
Nose swabs parents & 21 & 8 & - \\
Mother & 11 & 3 & - \\
Father & 10 & 5 & - \\
Air samples & 34 & 7 & - \\
RSV & 26 & 4 & - \\
RV & 8 & 3 & - \\
Surface swabs & 11 & - & - \\
Bedrail & 5 & - & - \\
Datalogger & 6 & - & - \\
\hline
\end{tabular}

the RSV RNA quantities collected from the air. For the third patient in whose room RSV was collected from the air, both parents were RSV negative, and therefore the RSV RNA must have been expelled by the patient.

For one patient who was co-infected with RV, low amounts of RV RNA were collected from the air on multiple days. Except for one positive sample that was recovered from stage 1 (droplets $>7 \mu \mathrm{m}$ ), the remaining three $\mathrm{RV}$ positive air samples were consistently recovered from stage 3 of the cascade impactor. This stage collects aerosols in the size range of 3.3 to $4.7 \mu \mathrm{m}$, indicating that at the time of air sampling RV RNA was contained in smaller particles than RSV RNA. Remarkably, on a day that the airway samples collected from the patient and both parents were negative for RV RNA, an air sample turned out to be positive. It is unclear if virus was still shed by the patient or the parents, but from an anatomical site of the respiratory tract that was not sampled, or that the air was contaminated by hospital personnel that was present that day.

Air sampling was only started a few days to one week after symptom onset during the late phase of infection, which may explain the low quantities of RSV and RV RNA collected from the air (Table 2). In several other studies, in which various air samplers were used, also low numbers of RSV RNA positive air samples were reported, with a detection rate ranging from 2.3 to $31.8 \%$ [12-14, 16]. Moreover, in a recent study by Chamseddine et al., none of the collected air samples around RSV infected patients were positive for RSV RNA, while half of the air samples collected around influenza A virus-infected patients were positive for influenza virus RNA. However, attempts to isolate infectious influenza virus from these samples were not successful [15].
Contrasting results were previously reported by Kulkarni et al., where air sampling around infants with RSV-confirmed bronchiolitis in general wards of a pediatric hospital resulted in the collection of high amounts of infectious RSV from the air [17]. Although viral quantities in the air decreased with increasing distance to the patient's head, up to $10^{5.6}$ plaque forming units (PFU) of infectious RSV were still collected $5 \mathrm{~m}$ away from the patient's head. As in the present study, Kulkarni and colleagues used a six-stage Andersen cascade impactor, however, liquid medium was used as a collection medium. We have recently shown in an in-vitro setup that the collection of infectious virus using liquid medium is less efficient than when semi-solid gelatin is used (as in the current study), so this does not explain the differences in collected amounts of RSV between the studies [19]. It should be noted that the Andersen cascade impactor was designed and validated with solid impaction media rather than liquids [18].

The small amounts of RSV RNA detected in large droplets and the total absence of infectious RSV in the air around infected infants as presented here, and the low detection rates of RSV RNA in the air in most other studies using various air samplers, indicate that transmission via the air is unlikely to be a route by which RSV spreads in the population. This observation is also supported by the fact that room-sharing of RSV infected and noninfected patients did not seem to influence the risk of nosocomial infections [21]. In addition, wearing gowns and gloves, and adhering to strict hygiene has been shown to reduce the risk of nosocomial RSV transmission considerably, further indicating that aerosol transmission is not efficient and possibly negligible in this context [22, 23].

To investigate the possibility of RSV transmission through fomites, we also took surface swabs of the bedrails and dataloggers on the last day of air sampling. In none of the surface swabs, RSV RNA was detected by qRT-PCR, which is in contrast to the study of Wan et al., where RSV RNA was detected on various objects [12]. A reason for the conflicting results might be the timepoint when the surface swabs were taken. Wan and colleagues took surface swabs shortly after the admission of patients. In our study, surface swabs were only taken on the last day of air sampling, during the late stage of RSV infection when RSV RNA levels in the patients had already decreased.

\section{Conclusions}

In conclusion, we here demonstrate that despite the shedding of infectious RSV from the nasopharynx of hospitalized infants, no or only low amounts of RSV RNA were detected, but no infectious RSV was detected in any of 
the collected air samples. RSV RNA was only detected in large droplet samples on only a limited number of days. These results suggests that in the current hospital setting, RSV transmission through the air at later stages of infection was negligible and that the implementation of contact and droplet precautions, as currently employed in most hospitals, is sufficient.

\begin{abstract}
Abbreviations
ACH: Air changes per hour; Ct: Cycle threshold; DMEM: Dulbecco's Modified Eagle Medium; LPM: Liters per minute; LRTI: Lower respiratory tract infection; MEM: Minimum Essential Medium; PFU: Plaque forming unit; qRT-PCR: real time quantitative reverse transcription polymerase chain reaction; RSV: Respiratory Syncytial Virus; RV: Rhinovirus; $\mathrm{TCID}_{50}$ : 50\% Tissue culture infectious
\end{abstract} dose; UTM: Universal transport medium; VTM: Virus transport medium.

\section{Acknowledgements}

None.

\section{Authors' contribution}

JSK, JOW, RAMF, PLAF and SH conceptualized and designed the study. JSK and JOW planned and completed data collection. JSK, DM, TMB JJAK and RM conducted the sample processing and laboratory analysis. JSK, RAMF, PLAF and $\mathrm{SH}$ interpretated the data, and drafted the manuscript, which was critically reviewed and revised by all other authors. All authors read and approved the final manuscript.

\section{Funding}

This work was financed through an NWO VIDI (contract number 91715372) to SH and EU FP7 project PREPARE (602525). RAMF and SH were funded in part by the NIH/NIAID (contract HHSN272201400008C). PLAF and SH were funded in part by ZonMW (Netherlands Organization for Health and research development) Program 10430022010024. The funders had no role in the design of the study and collection, analysis, and interpretation of data and in writing the manuscript.

\section{Availability of data and materials}

All data and materials are available from the corresponding author (S.H.) on reasonable request.

\section{Declarations}

\section{Ethics approval and consent to participate}

This study was approved by the regional medical ethics committee "Medisch Ethische Toetsings Commissie (METC)" at the Erasmus Medical Center, Rotterdam, The Netherlands (MEC-2017-013 / NL59998.078.16).

\section{Consent for publication}

Not applicable.

\section{Competing interests}

The authors declare that they have no competing interests.

\section{Author details}

${ }^{1}$ Department of Viroscience, Erasmus University Medical Center, Dr. Molewaterplein 50, 3015 GE Rotterdam, The Netherlands. ${ }^{2}$ Department of Pediatrics, Reinier de Graaf Hospital, Delft, The Netherlands. ${ }^{3}$ Department of Pediatrics, Subdivision Infectious Diseases, Immunology and Rheumatology, Erasmus MC - Sophia, Rotterdam, The Netherlands.

Received: 2 February 2021 Accepted: 3 June 2021

Published online: 30 June 2021

\section{References}

1. Nair H, Nokes DJ, Gessner BD, Dherani M, Madhi SA, Singleton RJ, et al. Global burden of acute lower respiratory infections due to respiratory syncytial virus in young children: a systematic review and meta-analysis. Lancet. 2010;375:1545-55.

2. Shi T, McAllister DA, O'Brien KL, Simoes EAF, Madhi SA, Gessner BD, et al. Global, regional, and national disease burden estimates of acute lower respiratory infections due to respiratory syncytial virus in young children in 2015: a systematic review and modelling study. Lancet. 2017;390:946-58.

3. Mufson MA, Orvell C, Rafnar B, Norrby E. Two distinct subtypes of human respiratory syncytial virus. J Gen Virol. 1985;66:2111-24.

4. Grilc E, Prosenc Trilar K, Lajovic J, Sočan M. Determining the seasonality of respiratory syncytial virus in Slovenia. Influenza Other Respir Viruses. 2021:15:56-63.

5. Yu J, Liu C, Xiao Y, Xiang Z, Zhou H, Chen L, et al. Respiratory syncytial virus seasonality, Beijing, China, 2007-2015. Emerg Infect Dis. 2019;25:1127-35.

6. Mlinaric-Galinovic G, Vojnovic G, Cepin-Bogovic J, Bace A, Bozikov J, Welliver RC, et al. Does the viral subtype influence the biennial cycle of respiratory syncytial virus? Virol J. 2009:6:1-6.

7. Gilca R, De Serres G, Tremblay M, Vachon ML, Leblanc E, Bergeron MG, et al. Distribution and clinical impact of human respiratory syncytial virus genotypes in hospitalized children over 2 winter seasons. J Infect Dis. 2006:193:54-8.

8. Miron D, Srugo I, Kra-Oz Z, Keness Y, Wolf D, Amirav I, et al. Sole pathogen in acute bronchiolitis: is there a role for other organisms apart from respiratory syncytial virus? Pediatr Infect Dis J. 2010;29:7-10.

9. Smith DK, Seales S, Budzik C, Jacksonville NH. Respiratory syncytial virus bronchiolitis in children. Am Fam Phys. 2017;95:94-9.

10. Kutter JS, Spronken MI, Fraaij PL, Fouchier RA, Herfst S. Transmission routes of respiratory viruses among humans. Curr Opin Virol. 2018;28:142-51.

11. Hall CB, Douglas RG. Modes of transmission of respiratory syncytial virus. J Pediatr. 1981;99(1):100-3.

12. Wan GH, Huang CG, Chung FF, Lin TY, Tsao KC, Huang YC. Detection of common respiratory viruses and mycoplasma pneumoniae in patientoccupied rooms in pediatric ards. Medicine (Baltimore). 2016;95:e3014.

13. Lindsley WG, Blachere FM, Davis KA, Pearce TA, Fisher MA, Khakoo R, et al. Distribution of airborne influenza virus and respiratory syncytial virus in an urgent care medical clinic. Clin Infect Dis. 2010;50:693-8.

14. Grayson SA, Griffiths PS, Perez MK, Piedimonte G. Detection of airborne respiratory syncytial virus in a pediatric acute care clinic. Pediatr Pulmonol. 2017:52:684-8.

15. Chamseddine A, Soudani N, Kanafani Z, Alameddine I, Dbaibo G, Zaraket $\mathrm{H}$, El-Fadel M. Detection of influenza virus in air samples of patient rooms. J Hosp Infect. 2020;108(2021):33-42

16. Aintablian N, Walpita P, Sawyer M. Detection of bordetella and respiratory virus in air samples. Infect Control Hosp Epidemiol. 1998;19:918-23.

17. Kulkarni H, Smith CM, Lee DDH, Hirst RA, Easton AJ, O'Callaghan C. Evidence of respiratory syncytial virus spread by aerosol time to revisit infection control strategies? Am J Respir Crit Care Med. 2016;194:308-16.

18. Andersen AA. New sampler for the collection, sizing and enumeration of viable airborne particles. J Bacteriol. 1958;76:471-84.

19. Kutter JS, et al. Comparison of three air samplers for the collection of four nebulized respiratory viruses — collection of respiratory viruses from air. Indoor Air. 2020. https://doi.org/10.1111/ina.12875.

20. Hoek RAS, Paats MS, Pas SD, Bakker M, Hoogsteden HC, Boucher CAB, et al. Incidence of viral respiratory pathogens causing exacerbations in adult cystic fibrosis patients. Scand J Infect Dis. 2013;45:65-9.

21. Bekhof J, Bakker J, Reimink R, Wessels M, Langenhorst V, Brand PLP, Ruijs GJHM. Co-infections in children hospitalised for bronchiolitis: role of roomsharing. J Clin Med Res. 2013;5:426-31.

22. Hall CB. Nosocomial respiratory syncytial virus infections: the "cold war" has not ended. Clin Infect Dis. 2000;31:590-6.

23. Bont L. Nosocomial RSV infection control and outbreak management. Paediatr Respir Rev. 2009;10:16-7.

\section{Publisher's Note}

Springer Nature remains neutral with regard to jurisdictional claims in published maps and institutional affiliations. 